\title{
ARE REVENUES COMPARABLE? THE CASE OF EUROPEAN GAMBLING COMPANIES
}

\author{
Eva Karai ${ }^{175}$ \\ Judit Nagy ${ }^{176}$ \\ Janos Erdei ${ }^{177}$ \\ Maria Lakatos ${ }^{178}$
}

https://doi.org/10.31410/itema.2018.438

\begin{abstract}
Gambling industry has its features, especially from accounting perspectives. The different regulations by countries may influence the accounting practices and so the form and content of the presented financial statements, shadowing the clearness of information used by decision-makers. Our study aims to provide an update report about the characteristics of the European industry using the financial statements of gambling companies and examine whether the variations in the recognition and measurement of revenue and gambling tax might have a significant impact on comparability and understandability of financial statements. As for European IFRS statements, empirical results show differences in the accounting of gaming revenue and gambling tax, depending on the country where the company was registered. If specific accounting guidance for the gambling sector existed, it would enhance the transparency of financial statements.
\end{abstract}

Keywords: gambling companies, IFRS, revenue recognition, gambling tax

\section{INTRODUCTION}

Tudies on European gaming industry mainly focused on social and health implications (i.e. Error! Reference source not found., [2], [3], [4]), on the role and effectiveness of gambling taxes (i.e. [5], [6]), meanwhile other researchers analyzed the financial performance of European casinos compared with casinos in the USA or Macau (i.e. [7], [8], [9]).

While corporate model became the normative organizational form of North America particularly in Las Vegas, the European casinos are operated under strict state control in the form of monopolies. [10]. At the end of the 20th century they were mainly government-owned, and force table games at the low rate of promotion and advertisement. Gambling taxes were sometimes so high, that state can be regarded as primary owner channeling the winning from the real and private ones. [7]

Gambling is regulated worldwide. The gambling operation requires concessions and a variety of licenses. Of course, a company may operate in different countries, and the regulations of these countries are generally different from each other. Thus, companies are also required to provide disclosures by geographical segment, and according to local regulations.

\footnotetext{
175 Eötvös Loránd University, HU-1053 Budapest, Egyetem tér 1-3., Hungary

${ }^{176}$ Budapest University of Technology and Economics, HU-1111 Budapest, Müegyetem rkp. 3., Hungary

${ }^{177}$ Budapest University of Technology and Economics, HU-1111 Budapest, Múegyetem rkp. 3., Hungary

${ }^{178}$ Eötvös Loránd University, 1053 Budapest, Egyetem tér 1-3, Hungary
} 
In today's world, dominated by the Internet, mobile applications and online games play an ever more significant role in the gaming sector, thereby helping to satisfy basic human needs [2]. Online gambling is legal in many countries and extends far across national borders. Some countries regulate the spread of online activity through very high taxes and the restriction of services. [11]

Our study aims to provide an updated report about the characteristics of the European industry using the financial statements of gambling companies and examine whether the variations in the recognition and measurement of revenue and gambling tax might have a significant impact on comparability and understandability of financial statements. Our research focuses on revenues of companies in the same industry but with different accounting treatment.

The direct and indirect presence of IFRS is very high in Europe. Despite the widespread use of IFRS, national traditions and practices, the language difficulties [12] and the differences between stakeholder groups and between countries [13] hamper and slow down the voluntary implementation or convergence of national regulations with IFRS.

Ahmed, Neel, and Wang [14] mentioned the revenue recognition as an area where the lack of implementation guidance may result in different interpretations and implementations. Revenue provides information about the realized gross earnings from companies' business activities, the size of a company; it is the basis for a large number of financial ratios in profitability analysis and the performance evaluation of the management of companies. [15]

The specific features in the gaming and gaming related activities enable that revenues can be recognized and presented in the financial statements of gambling entities differently. It can be presented theoretically in three levels. The sales revenue can include the gross wager (the total amount of bets) and the revenues from gaming-related activities. The gross gaming revenue is the difference between the amounts received and the amounts paid back to the players as gaming wins. In the case of net gaming revenue the gross gaming revenue is adjusted by incentives, changes in accrued jackpot liabilities or gaming tax.

The presentation of gambling revenue depends on the accounting practice applied by the entity, and the accounting practice may differ not only on the country level but even on company level because of lacking uniform guidance.

There is a close relationship between the accounting for gaming revenues and gambling tax. Gambling markets are typically taxed differently than the other part of the economy and alter by countries. [16] In the gaming industry, three categories of tax levies exist: the company income tax, the gambling tax - as an excise tax-, and personal income tax on winnings.

Figure 1: Categories of tax levies on gambling

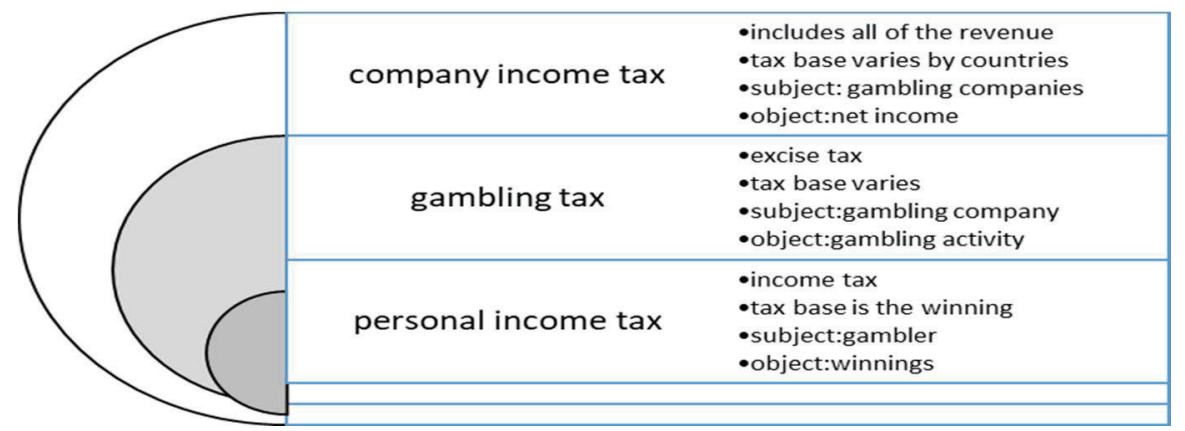


The accounting treatment of gambling tax differs even by IFRS companies. When gambling tax is considered a sales tax, it should be eliminated, deducted from revenue. According to the definition under IAS 12, however, a gaming tax may qualify as income tax. If gaming tax does not qualify as sales tax nor an income tax, companies account it as an expense.

\section{METHODOLOGY AND DATA}

Our research aims at investigating gambling companies in Europe for which non-consolidated financial accounts of entities were extracted from the Amadeus database, covering a period from 2004 to 2013. Our search request brought more than 19,000 results for companies operating in the gambling business in 41 European countries. This sample is believed to cover the essence of the European gambling market. Amadeus provided appropriate data for all 19,000 companies regarding their size and region. We excluded more than 8,400 companies for which data on operating revenue was not available in the period examined. Therefore the scope of the analyses has been restricted to the dataset of 10,590 companies. Our data collection cannot be considered randomly, so statistically, the available sample cannot be representative either. Regarding its proportion and size, the sample itself is significant, which indicates that our assessments and conclusions can be considered well-founded.

In our research, we classified the companies into four categories: small, medium, large and very large according to the values of operating revenues and total assets, and the number of employees.

Based on the database retrieved from Amadeus, we assigned the companies to their countries, and then we classified the countries into the following six groups of geographical regions: Northern Europe, Western Europe, Central Europe, Eastern Europe, Southeast Europe, and Southern Europe. We examined the relations based on the p-value, and if we found any relation, the power of the association we evaluated by the Cramer coefficient.

When analyzing the companies' income, instead of sales values we used the operating revenue values, because this data was available for many more companies. For those companies where both sales and operating revenue values were available, we examined the difference between the two values, and we found no material difference.

To justify the concentration of the operating revenue, we have done concentration analysis, and we illustrated the results with Lorenz curve, and we measured the extent of the concentration with Gini-index.

During our analysis, we filtered those companies from the pattern, of whom the operating revenue for the year 2004 and 2013 was not higher than ten thousand euro's. After the filtration have remained 2908 companies. These companies have been clustered based on their accounting system: whether they prepare the financial statements on IFRS or national accounting basis.

In order to assess the impact of different accounting treatments, we examined some income statements and notes of top 10 country's large and very large companies, to reveal form and content of disclosures of revenue and gambling tax. 


\section{GAMBLING INDUSTRY IN EUROPE}

Examining the companies by countries, we noticed that at least half of the gambling companies are small companies, and there are countries where we found no small or medium-sized companies at all. In Monaco and Montenegro, we found one large company, in Belarus we found two gambling companies classified into the large category. In Greece, there is a notable lack of small companies representing only $9 \%$ of gambling companies. Nearly one-third of companies in the very large category are registered in the United Kingdom (27\%), while 17\% are run in the Russian Federation, then in Germany, the Czech Republic, Italy, and Malta. Combining the large and very large categories, we can declare that most large companies operated in the United Kingdom, in Spain, and Italy. Among the Central European countries, Romania with 51 and the Czech Republic with 40 large companies are also in the top 10.

Regarding company sizes by regional distribution, we found significant differences between the regions, but at the same time, the associative relationship was weak. The result of the Chisquared test was $\chi 2=557.3, p=0.000$, but Cramér's V was 0.1 , which indicates a relatively weak relationship between the two factors.

Figure 2: Company categories by geographical areas

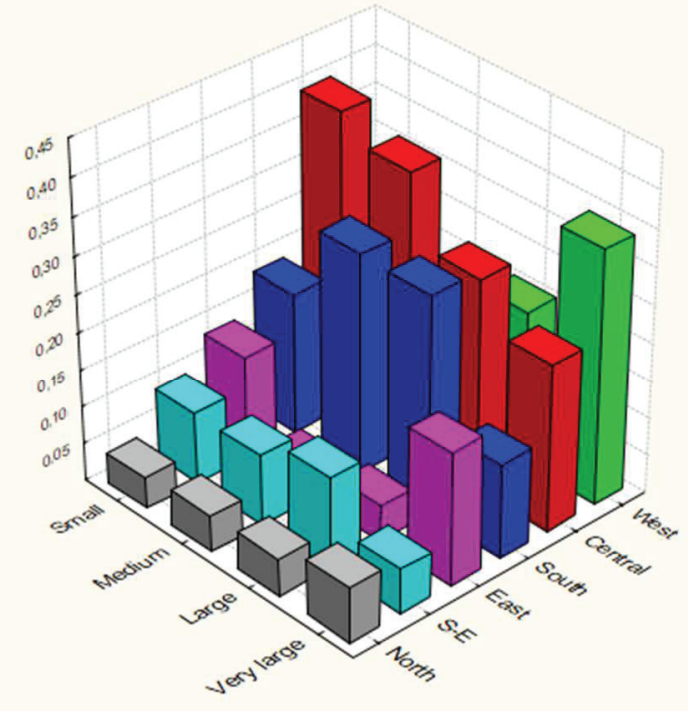

Overall, we can declare that in the Western and Northern regions the large and very large company categories are more typical; in Central and Eastern Europe, we find mainly mid-sized and small companies; and in Southern Europe, there are more mid-sized and large companies. More than half of the online companies examined are located in the Southern region, while in the Western region two-thirds of the companies are large and very large companies.

Regarding company size, the majority (79\%) of companies are small, while only $5 \%$ of companies belong to the categories of large and very large companies. At the same time, examining the data on operating revenue, we perceive an inverse relationship. Small companies represent less than $5 \%$ of the annual operating revenue, while the fair proportion of the large and very large companies is approximately $90 \%$. These ratios suggest that the gambling market is highly concentrated. 
Illustrating the data in 2004 and 2013 on a Lorenz curve, we can see that the curve is almost the same in the two years: both of them show a very high concentration. Gini indexes exceed the value of 0.95 , which indicates exceptionally high concentration. In this context, nothing has changed over the ten years: concentration has been the same year by year.

Figure 3: Lorenz curve 2013 and 2004

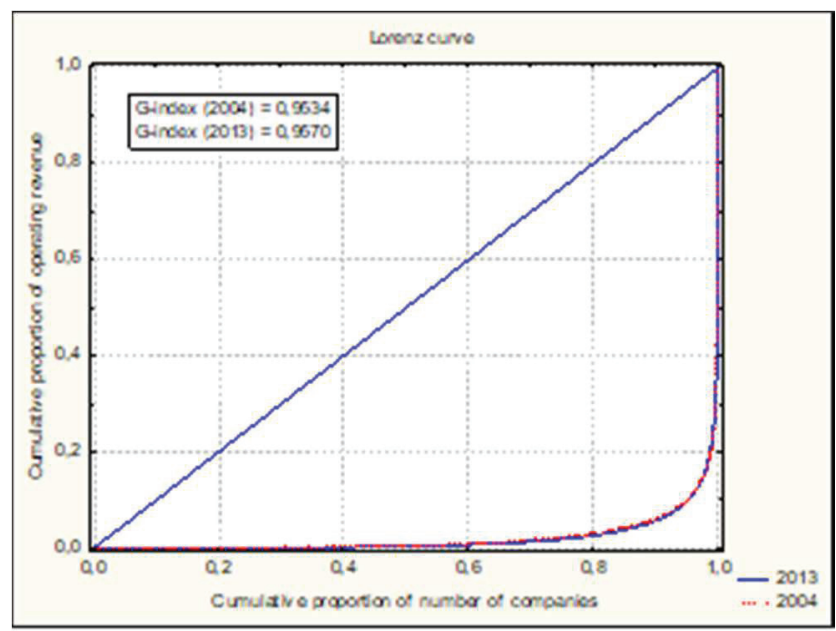

The highest operating revenue through the analyzed period is generated in Western Europe, followed by the Northern region, and finally in the Central region. According to activity, analyzing the data in 2013, we found that $44 \%$ of the total revenue was represented by only 13 companies of mixed type; which is almost as much as the revenue of 129 land-based companies. Filtered by country, the highest operating revenue is generated in the United Kingdom, exceeding all other countries in the period examined. Almost 50\% of the total revenue in 2013 was earned by those British companies that rank first; including a mixed company, whose revenue represents $80 \%$ of British revenues.

Figure 4: Top 10 countries based on operating revenue between 2004 and 2013 (in EUR)

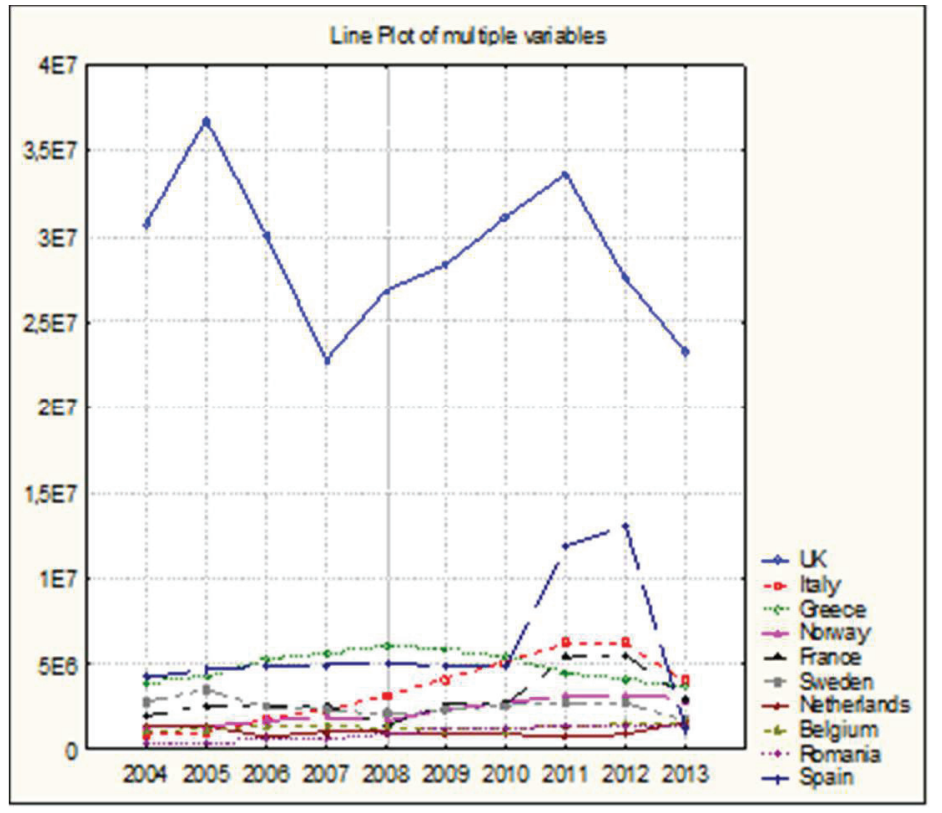




\section{RECOGNITION OF GAMBLING REVENUE AND TAX}

Concerning revenue and gaming tax recognition, empirical results show notable differences in the European domestic and IFRS statements.

In Europe, gaming taxes are generally levied progressively by ranges based on gross gaming revenue expressed by percentage, except Hungary and Poland, here we can find a fixed percentage. [17]. We found countries such as Lithuania and the Republic of Estonia where there are fixed taxes. Generally, for online activities, the tax rate is lower, compared to the tax rate of land-based activities. [17]

Some of the companies recognize gambling tax as an expense, while other companies deduct it from their revenue. For the countries examined, recognition of the gambling tax as a sales taxthus the deduction of it from their revenue-is applied in Italy and France. Recognition of the revenue is on a net basis; thus bonuses, allowances, benefits, and tax should be deducted from the amount of the revenue from the products and goods sold and services provided. In other countries, gambling tax, similar to other operating taxes, is recognized as an expense.

Our empirical results show that recognition of the gambling tax as an expense is applied in UK, Spain, Switzerland, the Republic of Estonia and Hungary, although the ways of recognition are not uniform: in UK and Switzerland gambling tax is part of the cost of sales, in the Republic of Estonia, Spain and Hungary it is recognized as a separate operating expense.

According to the domestic regulations on accounting and the IFRS standards, the contents of the revenues differ, as where gambling tax is recognized as an expense, the revenue is higher by the amount of the gambling tax in the financial statement.

\section{DISCUSSION}

For the users of financial statements, revenues of a company are indicators of the financial performance and position or prospects of an entity. The different accounting methods are essential not only for the determination of the market share but for comparison with other countries' companies as well. High gambling tax in the indicators may cause a massive distortion, and it may affect users significantly in their rational decision-making. In the European gambling industry, in order to reach comparable results for the revenue-based key indicators, it may be necessary to correct the amount of revenue.

Comparability of financial statements plays a prominent role in the decision-making of current and potential investors, creditors and other users. For those users of financial statements, the revenues of a company are the main indicators of the entity's financial performance, position or future prospects. Information included in the financial statements is crucial to the stakeholders' decisions.

This study calls attention to this special service sector and the impact of applying different accounting treatments when preparing financial statements on the different underlying specifications. Not only the presented forms, but the contents differ from each other, shadowing the clearness of information used by decision-makers. If specific accounting guidance or interpretation for the gambling sector existed, it would enhance the transparency of financial statements. 


\section{REFERENCES}

[1] Beco, E. (1996). Prevalence surveys of problem and pathological gambling in Europe: The cases of Germany, Holland and Spain. Journal of Gambling Studies, 12(2), 179-192.

[2] Demetrovics, Z., Urbán, R., Nagygyörgy, K., Farkas, J., Zilahy, D., Mervó, B., Reindl, A., Ágoston, C., Kertész, A. \& Harmath, A. (2011). Why do you play? The development of the Motives for Online Gaming Questionnaire (MOGQ). Behavior Research Methods, 43(3), 814-825.

[3] Körmendi, A. (2011). Cognitive distortions and personality traits in gambling players. (In Hungarian: Kognitív torzitások és személyiségvonások vizsgálata szerencsejátékosoknál). University of Debrecen.

[4] Planzer, S., Gray, H. M., \& Shaffer, H. J. (2014). Associations between national gambling policies and disordered gambling prevalence rates within Europe. International Journal of Law and Psychiatry, 37(2), 217-229.

[5] Paton, D., Siegel, D. S., \& Vaughan Williams, L. (2002). A policy response to the ecommerce revolution: the case of betting taxation in the UK. The Economic Journal, 112(480).

[6] Philander, K. S. (2013). A normative analysis of gambling tax policy. UNLV Gaming Research \& Review Journal, 17(2), 2.

[7] Gu, Z. (2002). Performance gaps between US and European casinos: A comparative study. UNLV Gaming Research \& Review Journal, 6(2), 53.

[8] Gu, Z., \& Gao, J. Z. (2006). Financial competitiveness of Macau in comparison with other gaming destinations. UNLV Gaming Research \& Review Journal, 10(2), 1.

[9] Eadington, W. R. (2011). After the great recession: The future of casino gaming in America and Europe. Economic Affairs, 31(1), 27-33.

[10] Thompson, W. N. (1998). Casinos de juegos del mundo: A survey of world gambling. The ANNALS of the American Academy of Political and Social Science, 556(1), 11-21.

[11]Finger, R. (2013, Jun 30). Online Gambling: A Pastime Whose Time Has Come. Forbes. Retrieved from http://www.forbes.com/sites/richardfinger/2013/06/30/online-gambling-apastime-whose-time-has-come/

[12]Andor, G. \& Rózsa, I. (2013). Should Codification emerge in IFRS? Does form of regulation matter? Acta Polytechnica Hungarica, 10(8), 187-204.

[13]Albu, C. N., Albu, N., Pali $\square$ Pista, S. F., Gîrbină, M. M., Selimoglu, S. K., Kovács, D. M., \& Strouhal, J. (2013). Implementation of IFRS for SMEs in Emerging Economies: Stakeholder Perceptions in the Czech Republic, Hungary, Romania and Turkey. Journal of International Financial Management \& Accounting, 24(2), 140-175.

[14]Ahmed, A. S., Neel, M., \& Wang, D. (2013). Does mandatory adoption of IFRS improve accounting quality? Preliminary evidence. Contemporary Accounting Research, 30(4), 1344-1372.

[15] Wagenhofer, A. (2014). The role of revenue recognition in performance reporting. Accounting and Business Research, 44(4), 349-379.

[16] Philander, K. S., Bernhard, B. J., Wimmer, B. S., Singh, A. K., \& Eadington, W. R. (2015). US casino revenue taxes and short-run labor outcomes. Journal of Policy Modeling, 37(1), 35-46.

[17]European Casino Association. (2015). ECA's European Casino Industry Report 2013. Retrieved from http://www.europeancasinoassociation.org/151.0.html

[18]Deloitte (2017) International Tax Highlits. Deloitte

[19]PWC (2016) Worldwide Tax Summaries. PWC 


\section{APPENDIX}

Table 1: Tax rate and base in casino industry (data sources: [17], [18], [19])

\begin{tabular}{|c|c|c|c|c|}
\hline & Casino nominal tax rate & Casino tax base & Company nominal tax rate & Company tax base \\
\hline Germany & $\begin{array}{l}\text { up to } 70 \% \\
30 \% \text { of the profit }\end{array}$ & $\begin{array}{l}\text { net revenue } \\
\text { profit }\end{array}$ & $\begin{array}{l}15 \% \text { normal rate }(15.825 \% \text {, } \\
\text { Including the solidarity } \\
\text { surcharge). } 14 \%-17 \% \\
\text { municipal trade tax }\end{array}$ & accounting profit \\
\hline Denmark & $60 \%$ o & net revenue & $23.5 \%$ & accounting profit \\
\hline Austria & 57,5 & net revenue & $25 \%$ & accounting profit \\
\hline France & $57,2 \%$ & net revenue & $33,3 \%$ standard rate & gross operating profit \\
\hline Luxembourg & $45 \%$ & net revenue & $\begin{array}{l}15(\text { reduced } \\
\text { rate }) / 19 \%(\text { standard rate })\end{array}$ & accounting profit \\
\hline Poland & $45 \%$ & net revenue & $\begin{array}{l}19 \% \text { (standard rate) } / 15 \% \\
\text { (reduced rate) }\end{array}$ & accounting profit \\
\hline Latvia & at least EUR 533.000 & license fee & $15 \%$ & accounting profit \\
\hline Malta & $29 \%$ & net revenue & $35 \%$ & $\begin{array}{l}\text { Taxable income includes } \\
\text { inter alia, } \\
\text { gains or profits derived } \\
\text { from a trade or business; }\end{array}$ \\
\hline Spain & $40,5 \%$ & net revenue & $\begin{array}{l}25 \% \text { general rate } \\
\text { special rates for banks } 35 \%\end{array}$ & accounting profit \\
\hline Portugal & $40 \%$ & net revenue & $\begin{array}{l}21 \% \text { standard corporate tax } \\
\text { rate. } 17 \% \text { reduced rate to } \\
\text { small and medium } \\
\text {-sized enterprises. }\end{array}$ & accounting profit \\
\hline Estonia & $18 \%$ & net revenue & $\begin{array}{l}20 \% \text { of the gross amount of } \\
\text { the profit distribution }\end{array}$ & $\begin{array}{l}\text { Corporate income tax } \\
\text { applied to company's } \\
\text { distributed profits (in lieu } \\
\text { of an annual } \\
\text { Corporate tax). }\end{array}$ \\
\hline Belgium & $17,6 \%$ & net revenue & $\begin{array}{l}33 \% \text { general rate } \\
\text { reduced rate for small and } \\
\text { medium } \\
\text {-sized companies at certain } \\
\text { circumstances }\end{array}$ & accounting profit \\
\hline Greece & $33 \%$ & $\begin{array}{l}\text { net revenue } \\
\text { plus different } \\
\text { types of other } \\
\text { tax rates and } \\
\text { concession fees }\end{array}$ & $29 \%$ & accounting profit \\
\hline Hungary & $21,66 \%$ & $\begin{array}{l}\text { net revenue on } \\
\text { average }\end{array}$ & $9 \%$ & accounting profit \\
\hline $\begin{array}{l}\text { United } \\
\text { Kingdom }\end{array}$ & $21 \%$ & net revenue & $\begin{array}{l}19 \% \text { regular rate } \\
25 \% \text { for artificial } \\
\text { arrangements of profit to } \\
\text { avoid the UK } \\
28 \% \text { at capital gains }\end{array}$ & $\begin{array}{l}\text { Corporation tax is } \\
\text { imposed on trading } \\
\text { income, several baskets of } \\
\text { non-trading income and } \\
\text { capital gains. }\end{array}$ \\
\hline Slovakia & fixed fee per annum & fixed fee & $\begin{array}{l}22 \% \text { and } 21 \% \text { for tax } \\
\text { periods } \\
35 \% \text { for taxable dividends } \\
\text { received from a non } \\
\text {-contracting state; }\end{array}$ & $\begin{array}{l}\text { Accounting profit } \\
\text { nondeductible and } \\
\text { nontaxable items. }\end{array}$ \\
\hline $\begin{array}{l}\text { Czech } \\
\text { Republic }\end{array}$ & $13 \%$ of the profit & profit & $\begin{array}{l}19 \% \text { regular rate } \\
5 \% \text { to basic investment } \\
\text { funds } \\
0 \% \text { to pension funds }\end{array}$ & accounting profit \\
\hline
\end{tabular}

